\title{
COUNTERFACTUAL ARguments In UnJUst ENRICHMENT
}

IN Vodafone Ltd. and Others v Office of Communications [2020] EWCA Civ 183, the Court of Appeal has considered - and rejected - counterfactual arguments advanced by the defendant in an unjust enrichment action grounded on the Woolwich unjust factor.

The action was brought by mobile network operators to recover licence fees paid to Ofcom under 2015 Regulations that were subsequently quashed (The Wireless Telegraphy (Licence Charges for the $900 \mathrm{MHz}$ frequency band and the $1800 \mathrm{MHz}$ frequency band) (Amendment and Further Provisions) Regulations 2015 (SI 2015/1709); EE Ltd. v Office of Communications [2017] EWCA Civ 1873). The Woolwich principle entitles anyone who pays to a public body taxes or levies that are not lawfully due to recover that money (Woolwich Equitable Building Society v Inland Revenue Commissioners [1993] A.C. 70). Ofcom's defence targeted the measure of restitution. It argued that the court should take account of the fact that, in the absence of the quashed 2015 Regulations, it would lawfully have charged licence fees at levels close to those set by the unlawful 2015 Regulations. Accordingly, it argued, the claimants should only recover their payments to the extent that they exceeded these hypothetical lawful charges.

The Wireless Telegraphy Act 2006 empowers Ofcom to set licence fees for mobile network operators. Prior to 2015, the Wireless Telegraphy (Licence Charges) Regulations 2011 (SI 2011/1128) fixed these rates. The invalid 2015 Regulations purported to amend the 2011 Regulations so as to raise licence fees to reflect full market value. As the 2015 Regulations were quashed, the 2011 Regulations remained in force. For two years, the mobile network operators were only liable at the lower 2011 rates but paid at the higher 2015 rates. In this action, they claimed restitution of the excess that they had paid over the amounts due under the 2011 Regulations. By contrast, the defendant argued that the appropriate measure was the excess paid over the hypothetical lawful Regulations that it would have introduced. As Ofcom could lawfully have levied equivalent sums to those levied under the invalid Regulations, this might significantly reduce the amount to be repaid.

The defendant's argument - in essence that it would have been entitled to an equivalent sum of money anyway - could affect each of the elements of an unjust enrichment claim. 
Ofcom denied that it was enriched, that the claimants were impoverished, that the enrichment was at their expense, and that the enrichment was unjust. Ofcom further argued that the full hypothetical value of using the licences should be "netted off" against the sums received.

Three principal authorities offered tentative support for the counterfactual argument: British Oxygen Co Ltd. v South of Scotland Electricity Board (No.2) [1959] 1 W.L.R. 587, Waikato Regional Airport Ltd. v Attorney General of New Zealand [2003] UKPC 50 and R. (Hemming (t/a Simply Pleasure Ltd.)) v Westminster City Council [2013] EWCA Civ 591. In each case, a public body was empowered by statute to set charges but there was a defect in the charge set. Those who paid the money recovered less than the full amount, on the understanding that the defendant could lawfully have charged a portion of the total, though it had not properly done so.

The claimants in Vodafone invoked the principles of legality and parity against the defendant's counterfactual argument. The principle of legality dictates that a public authority can only act within the bounds of its lawful authority. This principle was central to the determination of the case. Parity requires that those who paid the sums demanded by Ofcom should not be disadvantaged compared to a licence holder who refused to pay the unlawful fees. The desirability of such parity is part of the logic supporting the Woolwich principle, though not necessarily a formal principle (see [103]).

In the High Court, Adrian Beltrami Q.C. found for the claimants (Vodafone Ltd. v Office of Communications [2019] EWHC 1234 (Comm)). He found that it would never be permissible to hypothesise a change in the law to reduce the measure of restitution, as this would undermine the principle of legality. Ofcom's argument involved hypothesising new law to displace the existing 2011 Regulations. The trial judge differentiated between administrative steps and changes in primary or secondary legislation. He explained the previous authorities, in which public bodies were permitted to retain some portion of unlawfully-levied sums, as justified either by hypothesising purely administrative steps that would have legitimised a charge or by a retrospective power to set charges. This analysis left the door open for public authorities to make counterfactual arguments that they would have been entitled to impose charges if they had completed purely administrative steps. 
On appeal, Ofcom challenged the trial judge's finding that it was impermissible to hypothesise a change in secondary legislation, and argued that passing lawful regulations should be treated as an administrative step. By contrast, the mobile network operators submitted that it was not appropriate to hypothesise even omitted administrative steps in assessing the quantum of a Woolwich claim.

The Court of Appeal affirmed the trial judge's rejection of the appellant's proposed counterfactual principle. It further established that it is impermissible to take account of the hypothetical performance of even administrative steps. Sir Geoffrey Vos C. delivered the principal judgment. First, courts cannot reduce the sums recoverable in a Woolwich claim by reference to hypothetical new laws. This would require "uncharted speculation" and undermine the Woolwich principle (at [92]). Further, the courts have not hypothesised any counterfactual steps at all in Woolwich cases. The proper interpretation of the authorities is that the claimant can recover in unjust enrichment whatever sum exceeds what it could lawfully have been charged (at [82]). The question is not what the defendant would have done if it acted lawfully, but what charges the existing law entitled the defendant to receive. The court may determine this.

Applying this reasoning, the court could not take account of hypothetical steps, even administrative ones, that would have entitled Ofcom lawfully to charge higher licence fees than the existing Regulations allowed. Ofcom's arguments about enrichment and whether it occurred at the claimants' expense were predicated on recognising such hypothetical fees, and the Court of Appeal disposed quickly of these arguments. Ofcom was enriched at the respondents' expense, having received a direct transfer. There was no need to explore subjective devaluation. Lastly, Ofcom's netting-off argument presupposed valuing the licences at the higher, counterfactual, level rather than the valuation embodied in the valid 2011 Regulations. It followed that the respondents were entitled to restitution of the difference between what they paid and what was due under the valid 2011 Regulations.

The Vodafone judgment endorses the principle of legality as the foundation of the Woolwich right of recovery. Public bodies must respect the rule of law and adhere to the limits of the powers that the law grants them. The Woolwich principle prevents public bodies from retaining sums that they acquire without lawful authority. Reducing claims on the ground that 
the public body could have exacted the money lawfully - though it did not - would undermine this principle.

Although Woolwich cases belong to the private law of unjust enrichment, the rejection of counterfactual arguments because of the principle of legality shows that the distinctive public law policy which animates this unjust factor is also relevant when considering other elements of the claim. Courts are unlikely to accept arguments that would undermine the rationale for restitution in these cases. This recalls the judicially-expressed view that public authorities may not invoke the change of position defence to a Woolwich claim because it would subvert the underlying policy (Test Claimants in the FII Group Litigation v Revenue and Customs Commissioners [2014] EWHC 4302 (Ch) at [315]).

The Court of Appeal's judgment in Vodafone goes further than the High Court decision in excluding taking account of hypothetical administrative steps that would have provided a public body with a lawful basis for its receipts. This is comprehensible: even though it seems less objectionable to hypothesise purely administrative steps than changes to the law, the principle of legality still applies. If a public authority has not taken all administrative steps required to exercise a power to levy charges, then its exercise of that power is unauthorised.

Yet this exclusion of hypotheticals may not be as definitive as it seems. Following Vodafone, courts will in future assess the amount of charges that defendants could lawfully levy. It is conceivable that they may allow public body defendants the benefit of the doubt where they have not taken minor administrative steps to act on existing legislation. For instance, as the trial judge posited, a public body might omit minor formalities because it believed it was applying different rules. To what extent will the principle of legality as it operates in this private law context allow judges to overlook the non-completion of procedural requirements? Public law approaches concerning minor procedural defects may influence the assessment of what could lawfully be charged.

Lastly, a potentially interesting question remains concerning counter-restitution for benefits received in exchange for unlawful levies. In Vodafone, Ofcom chose not to seek counter-restitution for the value of the licences, preferring its netting-off argument based on a counterfactual valuation. In any event, as these claimants were liable for the fees set by the operative 2011 Regulations, they did not receive a valuable benefit free of charge. Were this 
otherwise, would the public authority be entitled to counter-restitution of the value of the benefit conferred by it (i.e., the licence), or might counter-restitution in some cases run up against an objection that it would undermine the principle of legality?

NIAMH CONNOLLY Address for Correspondence: UCL Laws, Bentham House, London WC1H OEG. Email: n.connolly@ucl.ac.uk 